\title{
KAJIAN ARSITEKTUR HIJAU DALAM PENGEMBANGAN DESAIN GEDUNG PEMERINTAHAN
}

\author{
Zahmi Afrizal \\ Program Studi Teknik Arsitektur, Akademi Teknik YKPN Yogyakarta \\ Jl. Gagak Rimang No. 1, Balapan, Yogyakarta \\ Email: afrizalzahmi@gmail.com
}

\begin{abstract}
Abstrak
Pertumbuhan pembangunan gedung terutama gedung pemerintahan berkembang pesat dan meningkat jumlah kebutuhannya di setiap daerah atau provinsi di Indonesia. Isu tentang permasalahan lingkungan yang ditimbulkan dari dampak pembangunan gedung pemerintahan di Indonesia pada saat ini seperti degradasi lingkungan, pemanasan global, krisis energi dan air menjadi latar belakang timbulnya konsep arsitektur hijau atau arsitektur ramah lingkungan. Komponen arsitektur hijau dalam gedung dan lingkungan kaitannya dengan pengelolaan tapak, efisiensi penggunaan energi, efisiensi penggunaan air, kualitas udara dalam ruang, material ramah lingkungan, pengelolaan sampah, pengelolaan air limbah, dan penempatan vegetasi menjadi suatu hal yang perlu diteliti. Hasil penelitian ini diharapkan dapat menjadi acuan dan pedoman desain pengembangannya pada gedung pemerintahan di Indonesia untuk menjadi bangunan gedung hijau yang ramah lingkungan.
\end{abstract}

Kata kunci: gedung pemerintahan, aristektur hijau, efisiensi energi.

\begin{abstract}
Title: Green Architecture Study in The Development of Government Building Designs

The development of constructing the building especially the government building develop rapidly and increasing the number of needs in each region or province in Indonesia. Issues concerning environmental problems resulting from the impact of the development of government buildings in Indonesia at this time such as environmental degradation, global warming, energy and water crises into the background of the emergence of the concept of green architecture or environmentally friendly architecture. The components of green architecture within the building and its environment relate to the site management, energy efficiency, water use efficiency, indoor air quality, environmentally friendly materials, waste management, wastewater management, and vegetation placement are necessary to be researched. The results of this study is expected to be a reference and design guidelines on the development of government buildings in Indonesia to become green buildings that are environmentally friendly.
\end{abstract}

Keywords: government buildings, green architecture, energy efficiency.

\section{Pendahuluan}

Semakin banyaknya isu perubahan iklim, pemanasan global, degradasi lingkungan, polusi udara, krisis energi dan krisis air yang dialami seluruh wilayah di dunia akibat dari perkembangan industri, transportasi, bangunan, dan kurangnya prilaku manusia yang peduli terhadap kualitas lingkungan, sehingga muncul gagasan Arsitektur Hijau (Green Architecture) yang merupakan upaya praktisi/peneliti di bidang arsitektur bangunan dan 
lingkungan binaan untuk lebih bijak dalam merencanakan dan mengelola bangunan dan lingkungan binaan dalam merespon dampak dari kondisi lingkungan yang terjadi saat ini.

Perkembangan pembangunan gedung berkontribusi terbesar dalam menghabiskan lebih dari $1 / 3$ sumber daya di dunia untuk tahap konstruksi dan pemanfaatannya, menggunakan $40 \%$ dari total energi global, menggunakan $12 \%$ dari total persediaan air bersih dan menghasilkan $40 \%$ dari total emisi gas rumah kaca. Sehingga pada tahun 2030, diperkirakan 1/3 total emisi gas rumah kaca yang mengasilkan $\mathrm{CO} 2$ di dunia berasal dari bangunan gedung, dengan penyumbang terbesar dari negaranegara di Asia (IPCC, 2007).

Dengan kondisi tersebut, Indonesia berkomitmen untuk menurunkan emisi Gas Rumah Kaca (GRK) dan mengurangi dampak negatif pembangunan gedung terhadap lingkungan sebesar $26 \%$ pada tahun 2020 (Perpres RAN-GRK, 2011).

Setelah diterbitkannya Permen PUPR No. 2 Tahun 2015 tentang Bangunan Gedung Hijau, maka komitmen pemerintah untuk mendorong pelaksanaan penerapan bangunan gedung hijau di Indonesia agar tercapai penurunan emisi dan mengurangi dampak negatif pembangunan gedung terhadap lingkungan sesuai dengan rencana $26 \%$ pada tahun 2020 perlu dilakukan percontohan. Sesuai dengan Rencana Strategis 2014-2019 direncanakan 32 gedung pemerintah (Gedung Pusat Informasi Pengembangan Permukiman dan Bangunan/PIP2B) akan dilakukan sertifikasi untuk menjadi bangunan gedung hijau. Secara bertahap dimulai tahun 2016 dilakukan penelitian dan pengamatan kinerja bangunan pada 6 gedung pemerintahan (gedung PIP2B) di provinsi Jawa Timur, Jawa Tengah, DIY, Bali, Sumatera Barat, dan Sulawesi Selatan. Selanjutnya hasil penelitian dan pengamatan kinerja bangunan sebagai acuan dan arahan desain untuk perencanaan dan penilaian kinerja gedung pemerintahan pada gedung PIP2B di provinsi lainnya sehingga secara optimal mampu memenuhi fungsi bangunannya, handal, dapat menjadi teladan bagi lingkungan sekitarnya, dan memberi kontribusi positif bagi penampilan gedung pemerintahan sebagai bangunan gedung hijau dan perkembangan arsitektur hijau di Indonesia.

\section{Permasalahan dan Tujuan}

Beberapa permasalahan yang terkait dengan kajian arsitektur hijau dalam pengembangan desain gedung pemerintahan, khususnya gedung PIP2B antara lain:

1. Tuntutan peraturan pemerintah yang mewajibkan setiap gedung pemerintahan menerapkan prinsip ramah lingkungan sebagai bangunan gedung hijau.

2. Mengidentifikasi faktor-faktor yang mempengaruhi atau mendukung konsep desain arsitektur hijau pada gedung pemerintahan.

Tujuan dari kajian arsitektur hijau dalam pengembangan desain gedung pemerintahan, khususnya gedung PIP2B antara lain:

1. Mewujudkan gedung pemerintahan sebagai percontohan bangunan gedung hijau di setiap provinsi atau daerah sehingga dapat menjadi acuan oleh masyarakat. 
2. Mengetahui faktor-faktor dan peluang penerapan arsitektur hijau pada gedung pemerintahan serta rekomendasi peningkatan efisiensi energi dan air.

\section{Kajian Pustaka}

Arsitektur Hijau (Green Architecture) adalah konsep arsitektur yang bertujuan meminimalkan konsumsi sumber daya alam, termasuk energi, air, dan material, serta meminimalkan timbulnya dampak negatif bagi lingkungan (Karyono, 2010).

Bangunan gedung hijau (green building) mengarah pada struktur dan pemakaian proses yang bertanggung jawab terhadap lingkungan dan hemat sumber daya sepanjang siklus hidup bangunan tersebut, mulai dari pemilihan tempat, desain, konstruksi, operasi, perawatan, hingga renovasi dan peruntuhan

(http://wikipedia.org/wiki/bangunanhij au, diakses pada 19 November 2016).

Prinsip-prinsip Arsitektur Hijau menurut Vale dan Brenda (1991) adalah:

1. Menghemat Energi (Conserving Energy)

Sungguh sangat ideal apabila menjalankan secara operasional suatu bangunan dengan sedikit mungkin menggunakan sumber energi yang langka atau membutuhkan waktu yang lama untuk menghasilkannya kembali. Solusi yang dapat mengatasinya adalah desain bangunan harus mampu memodifikasi iklim dan dibuat beradaptasi dengan lingkungan bukan merubah lingkungan yang sudah ada. Lebih jelasnya dengan memanfaatkan potensi matahari sebagai sumber energi. Cara mendesain bangunan agar hemat energi, antara lain:
- Bangunan dibuat memanjang dan tipis untuk memaksimalkan pencahayaan alami, penghawaan alami dan menghemat energi listrik.

- Memanfaatkan energi matahari yang terpancar dalam bentuk energi thermal sebagai sumber listrik dengan menggunakan alat photovoltaic yang diletakkan di atas atap. Sedangkan atap dibuat miring dari atas ke bawah menuju dinding Timur-Barat atau sejalur dengan arah peredaran matahari untuk mendapatkan sinar matahari yang maksimal.

- Memasang lampu listrik hanya pada bagian yang intensitasnya rendah. Selain itu juga menggunakan alat kontrol pengurangan intensitas lampu otomatis sehingga lampu hanya memancarkan cahaya sebanyak yang dibutuhkan sampai tingkat terang tertentu.

- Menggunakan sun screen pada jendela yang secara otomatis dapat mengatur intensitas cahaya dan energi panas yang berlebihan masuk ke dalam ruangan.

- Mengecat interior bangunan dengan warna cerah tapi tidak menyilaukan, yang bertujuan untuk meningkatkan intensitas cahaya.

- Bangunan tidak menggunakan pemanas buatan, semua pemanas dihasilkan oleh penghuni dan cahaya matahari yang masuk melalui lubang ventilasi.

- Meminimalkan penggunaan energi untuk alat pendingin $(A C)$ dan lift.

2. Memanfaatkan iklim dan sumber energi alami (Working with Climate)

Melalui pendekatan green architecture bangunan beradaptasi dengan 
lingkungannya. Hal ini dilakukan dengan memanfaatkan kondisi alam, iklim dan lingkungan sekitar ke dalam bentuk serta pengoperasian bangunan, misalnya dengan cara:

- Orientasi bangunan terhadap sinar matahari pada sisi Utara dan Selatan.

- Menggunakan sistem pengkondisian udara dan cross ventilation untuk mendistribusikan udara yang bersih dan sejuk ke dalam ruangan.

- Menggunakan tumbuhan dan air sebagai pengatur iklim. Misalnya dengan membuat kolam air di sekitar bangunan, tumbuhan / vegetasi pada lansekap dapat digunakan untuk mencegah radiasi matahari baik secara langsung atau dipantulkan sebelum mencapai permukaan bangunan. Selain itu aliran udara pada sebuah bangunan dapat dikendalikan oleh penghalang bias atau saringan yang dapat dibuat dari pohon.

- Menggunakan jendela dan atap yang sebagian bisa dibuka dan ditutup untuk mendapatkan pencahayaan dan penghawaan alami yang sesuai kebutuhan.

3. Menanggapi keadaan tapak pada bangunan (Respect for Site)

Perencanaan mengacu pada interaksi antara bangunan dan tapaknya. Hal ini dimaksudkan keberadaan bangunan baik dari segi konstruksi, bentuk dan pengoperasiannya tidak merusak lingkungan sekitar, dengan cara sebagai berikut:

- Mempertahankan kondisi tapak dengan membuat desain yang mengikuti bentuk tapak yang ada.

- Luas permukaan dasar bangunan yang kecil, yaitu pertimbangan mendesain bangunan secara vertikal.
- Menggunakan material lokal dan material yang tidak merusak lingkungan.

4. Memperhatikan bangunan (Respect for User)

Dalam proses perancangan suatu bangunan, penggunaan elemen bangunan sebaiknya memperhatikan kesesuaian dengan alam sekitar dan pengguna bangunan. Dengan kesesuaian tersebut maka akan memudahkan pengolahan dari bahan tersebut dan dapat memberikan rasa aman dan nyaman pada penggunanya. Penggunaan material nontoxic, ramah lingkungan, sistem berkelanjutan, dan daur ulang sangat dianjurkan.

5. Meminimalkan Sumber Daya Baru (Limitting New Resources)

Suatu bangunan seharusnya dirancang mengoptimalkan material yang ada dengan meminimalkan penggunaan material baru, dimana pada akhir umur bangunan dapat digunakan kembali untuk membentuk tatanan arsitektur lainnya. Penerapan elemen lingkungan pada bangunan merupakan salah satu upaya masuk ke dalam suatu lingkungan yang ada sehingga tidak menimbulkan kekontrasan dengan lingkungan sekitar bangunan.

\section{Holistic}

Memiliki pengertian mendesain bangunan dengan menerapkan 5 poin di atas menjadi satu dalam proses perancangan. Prinsip-prinsip arsitektur hijau pada dasarnya tidak dapat dipisahkan, karena saling berhubungan satu dengan yang lain. Secara parsial akan lebih mudah menerapkan prinsipprinsip tersebut. Oleh karena itu, sebanyak mungkin dapat mengaplikasikan arsitektur hijau yang ada secara keseluruhan sesuai potensi yang ada di dalam tapak. 
Ada 3 Komponen desain yang menjadi konsep dasar arsitektur hijau, antara lain:

1. Desain Bioklimatik (Bioclimatic Design)

Desain Bioklimatik adalah desain lingkungan buatan yang menggunakan bantuan elemen-elemen bangunan, kondisi lingkungan dan iklim sekitar (suhu udara, curah hujan, kelembaban, radiasi matahari) untuk menciptakan kondisi nyaman bagi pengguna bangunan (ERG, 1994).

a. Strategi Pasif

Desain Bioklimatik merupakan Strategi Pasif, strategi yang memanfaatkan energi alam semaksimal mungkin berupa curah hujan, orientasi matahari, iklim, pergerakan matahari dan angin yang terdiri dari:

- Orientasi Bangunan

- Konfigurasi Bangunan

- Selubung Bangunan (atap, dinding, lantai)

b. Aplikasi Strategi Pasif

- Aplikasi strategi pasif dapat diterapkan dalam berbagai desain komponen bangunan, seperti :

- Solar Control, untuk mereduksi sinar matahari yang masuk kedalam bangunan secara berlebihan.

- Material fasade yang dapat memantulkan panas sinar matahari, seperti kaca solar tap, kaca riben.

- Double Fasade, penggunaan bidang kulit bangunan secara berlapis.

- Daylighting/Pencahayaan alami.

- Ventilasi/Penghawaan alami.

Prinsip desain bioklimatik menurut Yeang (1996), dalam bukunya yang berjudul The Skyscraper, Bioclimatically Considered antara lain:

a. Penempatan Core

Core merupakan komponen inti bangunan yang di dalamnya terdapat ruang service/maintenance mekanikalelektrikal, tangga, dan lift. Selain sebagai bagian struktur (share wall), posisi core juga mempengaruhi kenyamanan termal. Penempatan posisi core pada sisi Barat atau Timur dapat dijadikan sebagai penghalang panas yang masuk ke dalam bangunan.

b. Penentuan Orientasi Bangunan

Orientasi bangunan sangat penting untuk menciptakan konservasi energi. Secara umum, susunan bangunan dengan bukaan menghadap Utara dan Selatan memberikan keuntungan dalam mengurangi insulasi panas. Orientasi bangunan yang terbaik adalah meletakkan luas permukaan bangunan terkecil menghadap Timur dan Barat memberikan dinding eksternal pada luar ruangan.

c. Penempatan Bukaan/Jendela

Bukaan/jendela harus menghadap Utara dan Selatan untuk mendapatkan orientasi pandangan. Menggunakan kaca jendela yang sejajar dengan dinding luar dengan menggunakan kaca dengan sistem Metrical Bioclimatic Window $(M B W)$. MBW didesain sebagai sistem elemen dengan fungsi yang dikhususkan untuk ventilasi, perlindungan tata surya, penerangan alami, dan area visualisasi. Sistem MBW bertujuan menurunan perolehan panas dari radiasi sinar matahari dan menggunakan penghawaan 
alami/ventilasi silang (cross ventilation).

d. Penggunaan Balkon

Menempatkan balkon dengan luasan yang cukup akan mudah membuat taman dan menanam tanaman yang dapat dijadikan pembayang sinar matahari secara alami.

e. Penggunaan Ruang Transisi

Ruang transisi dapat diletakkan di tengah dan sekeliling sisi bangunan. Ruang ini dapat menjadi ruang perantaran antara ruang dalam dan ruang luar bangunan (koridor).

f. Penggunaan Vegetasi

Mengintegrasikan antara elemen biotik (vegetasi) dengan elemen abiotik (bangunan) dapat memberikan efek dingin pada bangunan dan membantu proses penyerapan $\mathrm{O} 2$ dan pelepasan $\mathrm{CO} 2$.

g. Penggunaan Elemen Pembayang Pasif

Pembayang sinar matahari adalah esensi pembiasan sinar matahari pada dinding yang menghadap matahari secara langsung (pada daerah tropis berada di sisi Timur dan Barat). Elemen pembayang pasif dapat berupa sun shading (kisi-kisi), double façade, dan secondary skin.

\section{Desain yang Berkelanjutan (Sustainable Design)}

Sustainable Design adalah desain lingkungan buatan dengan prinsip ekonomi, sosial dan lingkungan yang berkelanjutan dalam menanggapi krisis energi dan lingkungan global. Prinsip Sustainable Design menurut Murcheff (1996), adalah:
- Low-impact material:

Memanfaatkan bahan/material yang ramah lingkungan.

- Efisiensi energi

Menggunakan atau membuat produk yang hanya membutuhkan sedikit energi.

- Kualitas dan daya tahan

Produk yang berfungsi baik (memiliki umur pakai) secara lama berarti mengurangi perawatan atau penggantian.

- Reuse and recycle

Rancangan suatu produk harus mempertimbangkan pemanfaatan secara berkelanjutan sampai dengan setelah masa pakai berakhir.

- Renewability

Bahan berasal dari wilayah terdekat, diproduksi dari sumber daya yang terbarukan, dan diolah menjadi sesuatu yang bermanfaat.

- Sehat

Produk yang tidak berbahaya bagi pengguna/penghuni dan lingkungan sekitarnya, bahkan bisa menunjang aspek kesehatan secara luas.

\section{Desain Ekologi (Ecology Design) \\ Desain Ekologi adalah desain lingkungan buatan yang memperhatikan interaksi antar makhluk hidup maupun interaksi antara makhluk hidup dengan lingkungannya (Hamzah \& Yeang, 2001).}

Dalam Desain Ekologi, Vegetasi sebagai Elemen Pendukung Arsitektur Hijau. Desain lansekap yang baik, tidak hanya sekadar lahan kosong, tetapi sebuah lahan yang dimanfaatkan sebagai taman yang didesain dan ditanami dengan berbagai macam vegetasi yang berfungsi sesuai kebutuhan. Penataan vegetasi disesuaikan dengan perletakan 
bangunan, agar tidak mengganggu dan merusak tata lingkungannya. Dalam hal ini vegetasi yang digunakan dalam lansekap bangunan sebaiknya dapat memberikan kesan rasa sejuk, kenyamanan dan ketenangan, sehingga dapat membantu proses kegiatan kerja (Frick dan Suskiyatno, 1998).

\section{Gambaran Umum Wilayah Studi}

Pada bagian ini akan dipaparkan mengenai profil lokasi kajian dan pengamatan tentang bangunan pemerintahan yang berada di jalan Kenari No.14A, Semaki, Umbulharjo, Kota Yogyakarta, DIY. Bangunan amatan adalah gedung Pusat Informasi Pengembangan Permukiman dan Bangunan (PIP2B). Bangunan ini milik pemerintah Provinsi DIY, Dinas Pekerjaan Umum, Perumahan dan Energi Sumber Daya Mineral. Fungsi bangunan ini sebagai gedung perkantoran. Gedung PIP2B terdiri dari 2 lantai dengan luas bangunan total $1566 \mathrm{~m}^{2}$, sedangkan luas tapak 6333 $\mathrm{m}^{2}$.

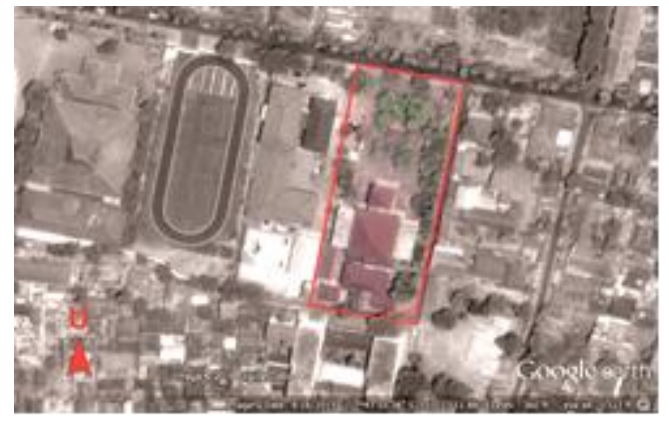

Gambar 1. Lokasi komplek Gedung PIP2B Sumber: Hasil survei, 2016

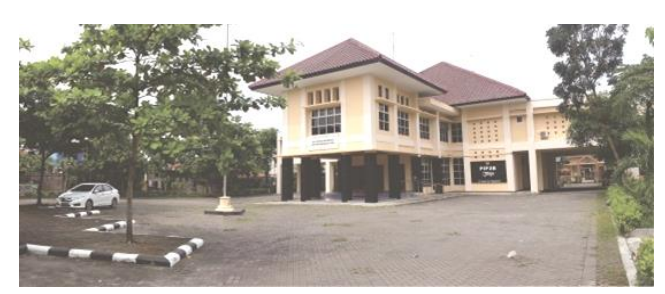

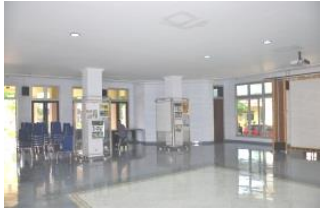

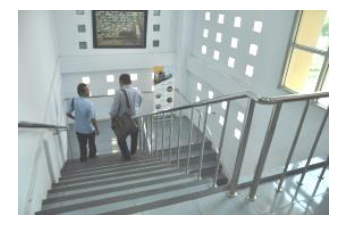

Gambar 2. Eksterior dan interior Gedung PIP2B

Sumber: Hasil survei, 2016

\section{Metode Penelitian}

Metode penelitian yang digunakan adalah metode deskriptif analisis dengan beberapa tahapan. Tahap pertama adalah mengumpulkan informasi tentang kajian arsitektur hijau pada gedung pemerintahan dalam kaitannya dengan aplikasi desain bioklimatik, desain yang berkelanjutan, dan desain ekologi. Tahap kedua adalah menganalisis unsur-unsur desain bioklimatik, desain yang berkelanjutan, dan desain ekologi yang sesuai digunakan pada gedung pemerintahan seperti menganalisis pengolahan tapak, efisiensi penggunaan energi, efisiensi penggunaan air, kualitas udara dalam ruang, material ramah lingkungan, pengelolaan sampah, pengelolaan air limbah dan penempatan persebaran vegetasi. Tahap ketiga adalah sintesis untuk menarik kesimpulan dari proses analisis dan konsep ini nantinya dapat dijadikan parameter dan rekomendasi/arahan desain gedung pemerintahan menuju bangunan gedung hijau.

\section{Pembahasan}

Dari data pengukuran, pengamatan dan pengkajian di lapangan didapatkan beberapa kriteria yang mendukung konsep arsitektur hijau pada gedung pemerintahan PIP2B untuk menuju bangunan gedung hijau, yaitu: 
1. Pengelolaan Tapak

a. Orientasi Bangunan

Orientasi façade bangunan PIP2B menghadap sisi Utara, sehingga bangunan ini adaptif terhadap pola edar matahari dan iklim mikro. Untuk dominasi bukaan berupa jendela dan ventilasi berada di sisi Timur dan Barat bangunan. Efek sinar matahari dari arah Timur dan Barat dapat menimbulkan silau dan panas yang sangat berlebihan, sehingga diperlukan barier dalam mereduksi dan meminimalkan rambatan radiasi matahari yang masuk ke dalam ruangan.

b. Aksesibilitas dan Sirkulasi

Aksesibilitas dan sirkulasi kendaraan dapat mengelilingi bangunan dengan 2 pintu gerbang di sisi Utara tapak sebagai akses masuk dan akses keluar kendaraan, serta 1 pintu gerbang di sisi Timur tapak sebagai akses evakuasi yang berfungsi ketika terjadi bencana atau keadaan darurat. Jalan utama di depan tapak, sebaiknya bisa diakses/dilewati jalur transportasi umum.

c. Penyediaan Jalur Pejalan Kaki

Penyediaan Jalur Pejalan kaki (pedestrian) pada gedung ini tidak terdapat pedestrian dengan arah yang mengakses antara luar gedung menuju ke teras gedung atau menerus dalam satu komplek gedung. Penyediaan fasilitas bagi pengguna sepeda, misal jalur khusus sepeda, tempat parkir sepeda belum diterapkan di area bangunan ini. Penambahan ramp bagi difabel pada akses masuk teras gedung dengan kemiringan sudut $7^{0}$ juga perlu diterapkan. d. Ruang Terbuka Hijau (RTH) Privat

Luas tapak pada area amatan adalah $6333 \mathrm{~m}^{2}$. Luas area bangunan di tapak adalah $783 \mathrm{~m}^{2}$, persentase luas area bangunan di tapak terhadap tapak keseluruhan adalah $12,36 \%$. Luas area hijau adalah $1066 \mathrm{~m}^{2}$, persentase luas area hijau terhadap tapak keseluruhan adalah 16,80\%. Persentase area tapak yang tertutup material paving blok untuk jalur sirkulasi kendaraan, plaza dan parkir $70,84 \%$, sehingga perlu adanya pengurangan luasan area paving blok untuk penambahan area resapan air/ruang terbuka hijau (RTH) menjadi $50 \%$.

2. Efisiensi Penggunaan Energi

a. Selubung Bangunan

Berdasarkan Peraturan Menteri Pekerjaan Umum dan Perumahan Rakyat No.2 tahun 2015 tentang Bangunan Gedung Hijau, standar selubung bangunan memiliki nilai OTTV kurang dari $35 \mathrm{Watt} / \mathrm{m}^{2}$ dan nilai perbandingan selubung bangunan transparan dengan selubung bangunan masif (Window to Wall Ratio) kurang dari 30\%. Penggunaan bahan selubung bangunan harus dapat mendukung efisiensi energi. Analisa Perhitungan OTTV dan WWR setiap sisi bangunan dengan mengidentifikasi material, menghitung luas permukaan bukaan, dinding masif, dan tritisan, serta menghitung luasan seluruh area façade/selubung gedung PIP2B menggunakan program excel dari Kementerian PUPR sebagai berikut: 


\section{Selubung Bangunan/Building Envelope Compliance Form (Orientasi Utara)}

Tabel 1. Identifikasi spesifikasi dinding eksterior

\begin{tabular}{|l|l|l|}
\hline Type & \multicolumn{1}{|c|}{ Konstruksi } & Warna \\
\hline EW 1 & Brick Wall & Coklat tua \\
\hline
\end{tabular}

Sumber: Hasil analisis, 2016

Tabel 2. Identifikasi spesifikasi sistem fenestrasi eksterior

\begin{tabular}{|c|c|c|c|c|c|c|c|}
\hline No & $\begin{array}{c}\text { Kode Tipe } \\
\text { Konstruksi } \\
\text { Sistem } \\
\text { Fenestrasi }\end{array}$ & Nama & SHGC & U Value & Peneduh & $\begin{array}{c}\text { Kode } \\
\text { Spesifikasi } \\
\text { Luar } \\
\text { Peneduh } \\
\text { Luar (lihat } \\
\text { tabel } 3,4,5)\end{array}$ & SC total \\
\hline 1 & F1 & $\begin{array}{l}\text { Single Glass } \\
\text { Clear } 8 \mathrm{~mm}\end{array}$ & 0,8 & 5,8 & yes & SE1 & 0,93 \\
\hline
\end{tabular}

Sumber: Hasil analisis, 2016

Tabel 3. Detail elemen peneduh luar

\begin{tabular}{|c|c|c|c|c|c|c|c|}
\hline C & Type : & EGGCRATE & & & & & \\
\hline \multirow{2}{*}{ No } & \multirow{2}{*}{$\begin{array}{l}\text { Kode } \\
\text { Peneduh } \\
\text { Luar } \\
\text { Vertikal }\end{array}$} & $\begin{array}{l}\text { panjang } \\
\text { (P1) }\end{array}$ & tinggi $(\mathrm{H})$ & $\begin{array}{l}\text { panjang } \\
\text { (P2) }\end{array}$ & lebar (W) & kemiringan & \multirow{2}{*}{ Sc ef } \\
\hline & & P1 (m) & $H(m)$ & $\mathrm{P} 2$ (m) & $W(m)$ & [derajat] & \\
\hline 1 & SE1 & 1 & 1,95 & 0,3 & 3,3 & 0 & 1,00 \\
\hline
\end{tabular}

Sumber: Hasil analisis, 2016

Tabel 4. Identifikasi façade

\begin{tabular}{|c|c|c|c|c|c|c|c|c|c|}
\hline \multirow{3}{*}{ No } & \multirow{3}{*}{ FASAD } & \multirow{2}{*}{$\begin{array}{l}\text { Tinggi } \\
\text { (jarak } \\
\text { antar } \\
\text { lantai) }\end{array}$} & \multirow[t]{2}{*}{ Panjang } & \multirow{2}{*}{$\begin{array}{c}\begin{array}{c}\text { Area } \\
\text { Fasad }\end{array} \\
{[1]} \\
\end{array}$} & \multirow{3}{*}{$\begin{array}{c}\text { Tipe } \\
\text { Konstruksi } \\
\text { Dinding }\end{array}$} & \multirow{3}{*}{$\begin{array}{l}\text { Kode Tipe } \\
\text { Konstruksi } \\
\text { Sistem } \\
\text { Fenestrasi }\end{array}$} & $\begin{array}{c}\text { Area } \\
\text { Bukaan }\end{array}$ & \multirow{3}{*}{$\begin{array}{c}\begin{array}{c}\text { Total } \\
\text { Jumlah } \\
\text { Lantai }\end{array} \\
{[3]} \\
\end{array}$} & \multirow{3}{*}{$\begin{array}{c}\begin{array}{c}\text { Total Area } \\
\text { Fasad }\end{array} \\
=[1] \times[3] \\
\left(\mathrm{m}^{2}\right)\end{array}$} \\
\hline & & & & & & & [2] & & \\
\hline & & (m) & (m) & $\left(m^{2}\right)$ & & & $\left(m^{2}\right)$ & & \\
\hline 1 & U 1 & 3,96 & 38,5 & 152,46 & EW 1 & F1 & 18,06 & 1 & 152,46 \\
\hline 2 & U 2 & 3,96 & 18,45 & 73,06 & EW 1 & F1 & 17,14 & 1 & 73,06 \\
\hline
\end{tabular}

Sumber: Hasil analisis, 2016 
Tabel 5. Perhitungan konduksi melalui dinding

\begin{tabular}{|c|c|c|c|c|c|c|c|c|c|}
\hline \multirow{4}{*}{ No } & \multirow[t]{2}{*}{ a ((1-WWR $\left.)^{*} \mathrm{Ww}^{*} \mathrm{Tdeq}\right)$} & $\begin{array}{l}\text { Total Area } \\
\text { Fasad }\end{array}$ & \multirow{2}{*}{$\begin{array}{c}\text { Heat } \\
\text { Absorbtion } \\
\text { Factor (a) }\end{array}$} & $\begin{array}{c}\text { Total Area } \\
\text { Bukaan }\end{array}$ & \multirow[t]{2}{*}{$\begin{array}{l}\text { Window to Wall } \\
\text { Ratio (WWR) }\end{array}$} & \multirow[t]{2}{*}{ 1-WWR } & $\begin{array}{c}\text { U Value (Uv) } \\
\text { wall }\end{array}$ & \multirow[t]{2}{*}{ TDek } & \multirow[t]{2}{*}{ OTTV } \\
\hline & & $\left(\mathrm{m}^{2}\right)$ & & $\left(m^{2}\right)$ & & & $\left(W / m^{2} k\right)$ & & \\
\hline & \multirow{2}{*}{ Façade } & (1) & (4) & (5) & (6) & (7) & (8) & (9) & (10) \\
\hline & & & & & $=(5) /(1)$ & $=1-(6)$ & & & $=(4) \times(7) \times(8) \times(9)$ \\
\hline$\cup 1$ & Brick Wall & 152,46 & 0,88 & 18,06 & 0,12 & 0,88 & 2,80 & 10,00 & 21,70 \\
\hline \multirow[t]{3}{*}{$\cup 2$} & Brick Wall & 73,06 & 0,88 & 17,14 & 0,23 & 0,77 & 2,80 & 10,00 & 18,84 \\
\hline & & 225,52 & & 35,20 & 0,16 & & & & \\
\hline & & TOTAL & & TOTAL & TOTAL & & & & \\
\hline
\end{tabular}

Sumber: Hasil analisis, 2016

Tabel 6. Perhitungan konduksi melalui bukaan

\begin{tabular}{|c|c|c|c|c|c|c|c|c|}
\hline \multirow{4}{*}{ No } & \multirow{2}{*}{$\left(W W R^{*} \mathrm{U}^{*} \Delta \mathrm{T}\right)$} & $\begin{array}{l}\text { Total Area } \\
\text { Fasad }\end{array}$ & $\begin{array}{l}\text { Total Area } \\
\text { Bukaan }\end{array}$ & \multirow{2}{*}{$\begin{array}{c}\text { Window to } \\
\text { Wall Ratio } \\
\text { (WWR) }\end{array}$} & $\begin{array}{l}\text { U Value } \\
\text { Bukaan }\end{array}$ & \multirow{2}{*}{$\Delta \mathrm{T}$} & \multirow{2}{*}{ OTTV } & (A) $\times$ OTTV \\
\hline & & $\left(\mathrm{m}^{2}\right)$ & $\left(m^{2}\right)$ & & $\left(\mathrm{W} / \mathrm{m}^{2} \mathrm{~K}\right)$ & & & (Watt) \\
\hline & \multirow{2}{*}{ Façade } & (1) & (2) & (3) & (4) & $(5)$ & (6) & (7) \\
\hline & & & & $=(2) /(1)$ & & & $=(3) \times(4) \times(5)$ & $=(1) \times(6)$ \\
\hline U 1 & $\begin{array}{l}\text { Single Glass Clear } \\
8 \mathrm{~mm}\end{array}$ & 152,46 & 18,06 & 0,12 & 5,80 & 5,00 & 3,44 & 523,74 \\
\hline \multirow[t]{3}{*}{ U 2} & $\begin{array}{l}\text { Single Glass Clear } \\
8 \mathrm{~mm}\end{array}$ & 73,06 & 17,14 & 0,23 & 5,80 & 5,00 & 6,80 & 497,06 \\
\hline & & 225,52 & 35,20 & 0,16 & & & & $1.020,80$ \\
\hline & & TOTAL & TOTAL & TOTAL & & & & TOTAL \\
\hline
\end{tabular}

Sumber: Hasil analisis, 2016

Tabel 7. Perhitungan radiasi melalui bukaan

\begin{tabular}{|c|c|c|c|c|c|c|c|c|}
\hline \multirow[t]{3}{*}{ No } & (WWR*SC*SF) & $\begin{array}{c}\begin{array}{c}\text { Total Area } \\
\text { Fasad }\end{array} \\
\left(\mathrm{m}^{2}\right)\end{array}$ & $\begin{array}{c}\begin{array}{c}\text { Total Area } \\
\text { Bukaan }\end{array} \\
\left(\mathrm{m}^{2}\right)\end{array}$ & $\begin{array}{c}\text { Window to } \\
\text { Wall Ratio } \\
\text { (WWR) }\end{array}$ & $\begin{array}{c}\text { Solar } \\
\text { Factor (SF) }\end{array}$ & $\begin{array}{c}\text { Shading } \\
\text { Coefficient } \\
\text { (SC=SCk'SCeff) }\end{array}$ & OTTV & $\begin{array}{c}\text { (A) } \times \text { OTTV } \\
\text { (Watt) }\end{array}$ \\
\hline & \multirow{2}{*}{ Façade } & (1) & (2) & (3) & (4) & (5) & (6) & (7) \\
\hline & & & & $=(2) /(1)$ & & & $=(3) \times(4) \times(5)$ & $=(1) \times(6)$ \\
\hline U 1 & $\begin{array}{l}\text { Single Glass Clear } \\
8 \mathrm{~mm} \\
\end{array}$ & 152,46 & 18,06 & 0,12 & 130,00 & 0,93 & 14,33 & 2.184,00 \\
\hline \multirow[t]{3}{*}{ U 2} & $\begin{array}{l}\text { Single Glass Clear } \\
8 \mathrm{~mm}\end{array}$ & 73,06 & 17,14 & 0,23 & 130,00 & 0,93 & 28,37 & $2.072,74$ \\
\hline & & 225,52 & 35,20 & 0,16 & & & & $4.256,74$ \\
\hline & & TOTAL & TOTAL & TOTAL & & & & TOTAL \\
\hline
\end{tabular}

Sumber: Hasil analisis, 2016

\section{Selubung Bangunan/Building Envelope Compliance Form (Orientasi Timur)}

Tabel 8. Identifikasi spesifikasi dinding eksterior

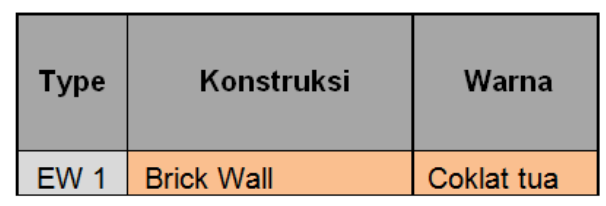

Sumber: Hasil analisis, 2016 
Tabel 9. Identifikasi spesifikasi sistem fenestrasi eksterior

\begin{tabular}{|c|c|c|c|c|c|c|c|}
\hline No & $\begin{array}{c}\text { Kode Tipe } \\
\text { Konstruksi } \\
\text { Sistem } \\
\text { Fenestrasi }\end{array}$ & Nama & SHGC & U Value & $\begin{array}{c}\text { Kode } \\
\text { Peneduh } \\
\text { Luar } \\
\left(\mathrm{W} / \mathrm{m}^{2} \mathrm{~K}\right)\end{array}$ & $\begin{array}{c}\text { Spesifikasi } \\
\text { Peneduh } \\
\text { Luar (linat } \\
\text { tabel } 3,4,5)\end{array}$ & SC $\times$ Scef \\
\hline 1 & F1 & $\begin{array}{l}\text { Single Glass } \\
\text { Clear 8mm }\end{array}$ & 0,8 & 5,8 & yes & SE1 & 0,63 \\
\hline
\end{tabular}

Sumber: Hasil analisis, 2016

Tabel 10. Detail elemen peneduh luar

\begin{tabular}{|c|c|c|c|c|c|c|c|}
\hline C & Type : & EGGCRATE & & & & & \\
\hline \multirow{2}{*}{ No } & \multirow{2}{*}{$\begin{array}{l}\text { Kode } \\
\text { Peneduh } \\
\text { Luar } \\
\text { Vertikal }\end{array}$} & $\begin{array}{l}\text { panjang } \\
\text { (P1) }\end{array}$ & tinggi $(\mathrm{H})$ & $\begin{array}{c}\text { panjang } \\
(\mathrm{P} 2)\end{array}$ & lebar (W) & kemiringan & \multirow{2}{*}{ Sc ef } \\
\hline & & P1 (m) & $H(m)$ & P2 (m) & $W(m)$ & [derajat] & \\
\hline 1 & SE1 & 1 & 1,95 & 0,3 & 3,15 & 0 & 0,68 \\
\hline
\end{tabular}

Sumber: Hasil analisis, 2016

Tabel 11. Identifikasi façade

\begin{tabular}{|c|c|c|c|c|c|c|c|c|c|}
\hline \multirow{3}{*}{ No } & \multirow{3}{*}{ FASAD } & \multirow{2}{*}{$\begin{array}{l}\text { Tinggi } \\
\text { (jarak } \\
\text { antar } \\
\text { lantai) }\end{array}$} & \multirow[t]{2}{*}{ Panjang } & \multirow{2}{*}{$\begin{array}{c}\begin{array}{c}\text { Area } \\
\text { Fasad }\end{array} \\
{[1]} \\
\end{array}$} & \multirow{3}{*}{$\begin{array}{c}\text { Tipe } \\
\text { Konstruksi } \\
\text { Dinding }\end{array}$} & \multirow{3}{*}{$\begin{array}{l}\text { Kode Tipe } \\
\text { Konstruksi } \\
\text { Sistem } \\
\text { Fenestrasi }\end{array}$} & $\begin{array}{c}\text { Area } \\
\text { Bukaan }\end{array}$ & \multirow{3}{*}{$\begin{array}{c}\begin{array}{c}\text { Total } \\
\text { Jumlah } \\
\text { Lantai }\end{array} \\
{[3]}\end{array}$} & \multirow{3}{*}{$\begin{array}{c}\begin{array}{c}\text { Total Area } \\
\text { Fasad }\end{array} \\
=[1] \times[3] \\
\left(\mathrm{m}^{2}\right)\end{array}$} \\
\hline & & & & & & & [2] & & \\
\hline & & (m) & (m) & $\left(m^{2}\right)$ & & & $\left(m^{2}\right)$ & & \\
\hline 1 & $\mathrm{~T} 1$ & 3,96 & 32,25 & 127,71 & EW 1 & F1 & 34,62 & 1 & 127,71 \\
\hline 2 & T2 2 & 3,96 & 25,75 & 101,97 & EW 1 & $\mathrm{~F} 1$ & 34,34 & 1 & 101,97 \\
\hline
\end{tabular}

Sumber: Hasil analisis, 2016

Tabel 12. Perhitungan konduksi melalui dinding

\begin{tabular}{|c|c|c|c|c|c|c|c|c|c|c|}
\hline \multirow{4}{*}{ No } & \multirow[t]{2}{*}{ a ((1-WWR)*UW'Tdeq) } & \begin{tabular}{c|} 
Total Area \\
Fasad
\end{tabular} & \multirow{2}{*}{$\begin{array}{c}\text { Heat } \\
\text { Absorbtion } \\
\text { Factor (a) }\end{array}$} & \multirow{2}{*}{\begin{tabular}{|c|}
$\begin{array}{c}\text { Total Area } \\
\text { Bukaan }\end{array}$ \\
$\left(\mathrm{m}^{2}\right)$ \\
\end{tabular}} & \multirow{2}{*}{$\begin{array}{l}\text { Window to Wall } \\
\text { Ratio (WWR) }\end{array}$} & \multirow[t]{2}{*}{ 1-WWR } & \multirow{2}{*}{\begin{tabular}{|c|}
$\begin{array}{c}\text { U Value (Uv) } \\
\text { wall }\end{array}$ \\
$\left(\mathrm{W} / \mathrm{m}^{2} \mathrm{k}\right)$ \\
\end{tabular}} & \multirow[t]{2}{*}{ TDek } & \multirow[t]{2}{*}{ OTTV } & $\begin{array}{l}\text { (A) } x \\
\text { OTTV }\end{array}$ \\
\hline & & $\left(\mathrm{m}^{2}\right)$ & & & & & & & & (Watt) \\
\hline & \multirow{2}{*}{ Façade } & (1) & (4) & (5) & (6) & (7) & (8) & (9) & (10) & (11) \\
\hline & & & & & $=(5) /(1)$ & $=1-(6)$ & & & $=(4) \times(7) \times(8) \times(9)$ & $=(1) \times(10)$ \\
\hline $\mathrm{T} 1$ & Brick Wall & 127,71 & 0,88 & 34,62 & 0,27 & 0,73 & 2,80 & 10,00 & 17,94 & 2.291,69 \\
\hline \multirow[t]{3}{*}{ T2 } & Brick Wall & 101,97 & 0,88 & 34,34 & 0,34 & 0,66 & 2,80 & 10,00 & 16,33 & $1.664,92$ \\
\hline & & 229,68 & & 68,96 & 0,30 & & & & & $3.956,61$ \\
\hline & & TOTAL & & TOTAL & TOTAL & & & & & TOTAL \\
\hline
\end{tabular}

Sumber: Hasil analisis, 2016 
ATRIUM, Vol. 3, No. 2, November 2017, 113-134

Tabel 13. Perhitungan konduksi melalui bukaan

\begin{tabular}{|c|c|c|c|c|c|c|c|c|}
\hline \multirow{4}{*}{ No } & \multirow[t]{2}{*}{$\left(W W R * U f^{*} \Delta T\right)$} & $\begin{array}{l}\text { Total Area } \\
\text { Fasad }\end{array}$ & $\begin{array}{c}\text { Total Area } \\
\text { Bukaan }\end{array}$ & \multirow{2}{*}{$\begin{array}{l}\text { Window to } \\
\text { Wall Ratio } \\
\text { (WWR) }\end{array}$} & $\begin{array}{l}\text { U Value } \\
\text { Bukaan }\end{array}$ & \multirow[t]{2}{*}{$\Delta \mathrm{T}$} & \multirow[t]{2}{*}{ OTTV } & (A) $\times$ OTTV \\
\hline & & $\left(\mathbf{m}^{2}\right)$ & $\left(\mathrm{m}^{2}\right)$ & & $\left(\mathrm{W} / \mathrm{m}^{2} \mathrm{~K}\right)$ & & & (Watt) \\
\hline & \multirow{2}{*}{ Façade } & (1) & (2) & (3) & (4) & (5) & (6) & (7) \\
\hline & & & & $=(2) /(1)$ & & & $=(3) \times(4) \times(5)$ & $=(1) \times(6)$ \\
\hline T 1 & $\begin{array}{l}\text { Single Glass Clear } \\
8 \mathrm{~mm}\end{array}$ & 127,71 & 34,62 & 0,27 & 5,80 & 5,00 & 7,86 & $1.003,98$ \\
\hline \multirow[t]{3}{*}{ Т 2} & $\begin{array}{l}\text { Single Glass Clear } \\
8 \mathrm{~mm}\end{array}$ & 101,97 & 34,34 & 0,34 & 5,80 & 5,00 & 9,77 & 995,86 \\
\hline & & 229,68 & 68,96 & 0,30 & & & & $1.999,84$ \\
\hline & & TOTAL & TOTAL & TOTAL & & & & TOTAL \\
\hline
\end{tabular}

Sumber: Hasil analisis, 2016

Tabel 14. Perhitungan radiasi melalui bukaan

\begin{tabular}{|c|c|c|c|c|c|c|c|c|}
\hline \multirow{4}{*}{ No } & \multirow[t]{2}{*}{$(\mathrm{WWR}$ SC*SF) } & $\begin{array}{l}\text { Total } \\
\text { Area } \\
\text { Fasad }\end{array}$ & $\begin{array}{c}\text { Total Area } \\
\text { Bukaan }\end{array}$ & \multirow{2}{*}{$\begin{array}{l}\text { Window to } \\
\text { Wall Ratio } \\
\text { (WWR) }\end{array}$} & \multirow{2}{*}{$\begin{array}{c}\text { Solar } \\
\text { Factor (SF) }\end{array}$} & \multirow{2}{*}{$\begin{array}{c}\text { Shading } \\
\text { Coefficient } \\
\text { (SC=SCk*SCeff) }\end{array}$} & \multirow[t]{2}{*}{ OTTV } & \multirow{2}{*}{$\begin{array}{c}\text { (A) } \times \text { OTTV } \\
\text { (Watt) }\end{array}$} \\
\hline & & $\left(m^{2}\right)$ & $\left(\mathbf{m}^{2}\right)$ & & & & & \\
\hline & \multirow{2}{*}{ Façade } & (1) & (2) & (3) & (4) & (5) & (6) & (7) \\
\hline & & & & $=(2) /(1)$ & & & $=(3) \times(4) \times(5)$ & $=(1) \times(6)$ \\
\hline T1 1 & Single Glass Clear $8 \mathrm{~mm}$ & 127,71 & 34,62 & 0,27 & 112,00 & 0,63 & 19,11 & $2.441,16$ \\
\hline \multirow[t]{3}{*}{ Т2 } & Single Glass Clear $8 \mathrm{~mm}$ & 101,97 & 34,34 & 0,34 & 112,00 & 0,63 & 23,75 & $2.421,42$ \\
\hline & & 229,68 & 68,96 & 0,30 & & & & $4.862,58$ \\
\hline & & TOTAL & TOTAL & TOTAL & & & & TOTAL \\
\hline
\end{tabular}

Sumber: Hasil analisis, 2016

Selubung Bangunan/Building Envelope Compliance Form (Orientasi Selatan)

Tabel 15. Identifikasi spesifikasi dinding eksterior

\begin{tabular}{|l|l|l|}
\hline Type & \multicolumn{1}{|c|}{ Konstruksi } & Warna \\
\hline EW 1 & Brick Wall & Coklat tua \\
\hline
\end{tabular}

Sumber: Hasil analisis, 2016

Tabel 16. Identifikasi spesifikasi sistem fenetrasi eksterior

\begin{tabular}{|c|c|c|c|c|c|c|c|}
\hline No & $\begin{array}{l}\text { Kode Tipe } \\
\text { Konstruksi } \\
\text { Sistem } \\
\text { Fenestrasi }\end{array}$ & Nama & SHGC & $\begin{array}{l}\text { U Value } \\
\left(\mathrm{W} / \mathrm{m}^{2} \mathrm{~K}\right)\end{array}$ & $\begin{array}{l}\text { Peneduh } \\
\text { Luar }\end{array}$ & $\begin{array}{c}\text { Kode } \\
\text { Spesifikasi } \\
\text { Peneduh } \\
\text { Luar (lihat } \\
\text { tabel } 3,4,5) \\
\end{array}$ & $\begin{array}{l}\text { SC total } \\
\text { SC } \times \text { Scef }\end{array}$ \\
\hline 1 & F1 & $\begin{array}{l}\text { Single Glass } \\
\text { Clear } 8 \mathrm{~mm}\end{array}$ & 0,8 & 5,8 & yes & SE1 & 0,93 \\
\hline
\end{tabular}

Sumber: Hasil analisis, 2016 
Tabel 17. Detail elemen peneduh luar

\begin{tabular}{|c|c|c|c|c|c|c|c|}
\hline C & Type : & EGGCRATE & & & & & \\
\hline \multirow{2}{*}{ No } & \multirow{2}{*}{$\begin{array}{c}\text { Kode } \\
\text { Peneduh } \\
\text { Luar } \\
\text { Vertikal }\end{array}$} & $\begin{array}{c}\text { panjang } \\
\text { (P1) }\end{array}$ & tinggi $(\mathrm{H})$ & $\begin{array}{l}\text { panjang } \\
\text { (P2) }\end{array}$ & lebar (W) & kemiringan & \multirow{2}{*}{ Sc ef } \\
\hline & & P1 (m) & $H(m)$ & P2 (m) & $W(m)$ & [derajat] & \\
\hline 1 & SE1 & 1 & 1,95 & 0,3 & 3,3 & 0 & 1,00 \\
\hline
\end{tabular}

Sumber: Hasil analisis, 2016

Tabel 18. Identifikasi façade

\begin{tabular}{|c|c|c|c|c|c|c|c|c|c|}
\hline \multirow{3}{*}{ No } & \multirow{3}{*}{ FASAD } & \multirow{2}{*}{$\begin{array}{l}\text { Tinggi } \\
\text { (jarak } \\
\text { antar } \\
\text { lantai) }\end{array}$} & \multirow[t]{2}{*}{ Panjang } & $\begin{array}{c}\text { Area } \\
\text { Fasad }\end{array}$ & \multirow{3}{*}{$\begin{array}{c}\text { Tipe } \\
\text { Konstruksi } \\
\text { Dinding }\end{array}$} & \multirow{3}{*}{$\begin{array}{l}\text { Kode Tipe } \\
\text { Konstruksi } \\
\text { Sistem } \\
\text { Fenestrasi }\end{array}$} & $\begin{array}{c}\text { Area } \\
\text { Bukaan }\end{array}$ & $\begin{array}{l}\text { Total } \\
\text { Jumlah } \\
\text { Lantai }\end{array}$ & $\begin{array}{c}\text { Total Area } \\
\text { Fasad }\end{array}$ \\
\hline & & & & [1] & & & [2] & [3] & $=[1] \times[3]$ \\
\hline & & (m) & (m) & $\left(m^{2}\right)$ & & & $\left(m^{2}\right)$ & & $\left(m^{2}\right)$ \\
\hline 1 & s 1 & 3,96 & 38,5 & 152,46 & EW 1 & F1 & 17,96 & 1 & 152,46 \\
\hline 2 & S 2 & 3,96 & 18,45 & 73,06 & EW 1 & F1 & 23,26 & 1 & 73,06 \\
\hline
\end{tabular}

Sumber: Hasil analisis, 2016

Tabel 19. Perhitungan konduksi melalui dinding

\begin{tabular}{|c|c|c|c|c|c|c|c|c|c|c|}
\hline \multirow{4}{*}{ No } & \multirow{2}{*}{ a ((1-WWR)"UW'Tdeq) } & \begin{tabular}{c|} 
Total Area \\
Fasad
\end{tabular} & \multirow{2}{*}{$\begin{array}{c}\text { Heat } \\
\text { Absorbtion } \\
\text { Factor (a) }\end{array}$} & $\begin{array}{c}\text { Total Area } \\
\text { Bukaan }\end{array}$ & \multirow{2}{*}{$\begin{array}{l}\text { Window to Wall } \\
\text { Ratio (WWR) }\end{array}$} & \multirow{2}{*}{$1-W W R$} & $\begin{array}{l}\text { U Value (Uv) } \\
\text { wall }\end{array}$ & \multirow{2}{*}{ TDek } & \multirow{2}{*}{ OTTV } & $\begin{array}{l}\text { (A) } x \\
\text { OTTV }\end{array}$ \\
\hline & & $\left(m^{2}\right)$ & & $\left(m^{2}\right)$ & & & $\left(W / m^{2} k\right)$ & & & (Watt) \\
\hline & \multirow{2}{*}{ Façade } & (1) & (4) & (5) & (6) & (7) & (8) & (9) & (10) & (11) \\
\hline & & & & & $=(5) /(1)$ & $=1-(6)$ & & & $=(4) \times(7) \times(8) \times(9)$ & $=(1) \times(10)$ \\
\hline s1 & Brick Wall & 152,46 & 0,88 & 17,96 & 0,12 & 0,88 & 2,80 & 10,00 & 21,72 & $3.311,12$ \\
\hline \multirow[t]{3}{*}{ s 2} & Brick Wall & 73.06 & 0.88 & 23.26 & 0,32 & 0,68 & 2,80 & 10,00 & 16,78 & $1.226,03$ \\
\hline & & 225.52 & & 41,22 & 0,18 & & & & & 4.537 .15 \\
\hline & & TOTAL & & TOTAL & TOTAL & & & & & TOTAL \\
\hline
\end{tabular}

Sumber: Hasil analisis, 2016

Tabel 20. Perhitungan konduksi melalui bukaan

\begin{tabular}{|c|c|c|c|c|c|c|c|c|}
\hline \multirow{4}{*}{ No } & \multirow[t]{2}{*}{$\left(W W R^{*} U F^{*} \Delta T\right)$} & $\begin{array}{c}\text { Total Area } \\
\text { Fasad }\end{array}$ & $\begin{array}{l}\text { Total Area } \\
\text { Bukaan }\end{array}$ & \multirow{2}{*}{$\begin{array}{l}\text { Window to } \\
\text { Wall Ratio } \\
\text { (WWR) }\end{array}$} & $\begin{array}{l}\text { U Value } \\
\text { Bukaan }\end{array}$ & \multirow[t]{2}{*}{$\Delta T$} & \multirow[t]{2}{*}{ OTTV } & (A) $\times$ OTTV \\
\hline & & $\left(\mathrm{m}^{2}\right)$ & $\left(\mathrm{m}^{2}\right)$ & & $\left(\mathrm{W} / \mathrm{m}^{2} \mathrm{~K}\right)$ & & & (Watt) \\
\hline & \multirow{2}{*}{ Façade } & (1) & (2) & (3) & (4) & $(5)$ & (6) & (7) \\
\hline & & & & $=(2) /(1)$ & & & $=(3) \times(4) \times(5)$ & $=(1) \times(6)$ \\
\hline S 1 & $\begin{array}{l}\text { Single Glass Clear } \\
8 \mathrm{~mm}\end{array}$ & 152,46 & 17,96 & 0,12 & 5,80 & 5,00 & 3,42 & 520,84 \\
\hline \multirow[t]{3}{*}{ S 2} & $\begin{array}{l}\text { Single Glass Clear } \\
8 \mathrm{~mm}\end{array}$ & 73,06 & 23,26 & 0,32 & 5,80 & 5,00 & 9,23 & 674,54 \\
\hline & & 225,52 & 41,22 & 0,18 & & & & $1.195,38$ \\
\hline & & TOTAL & TOTAL & TOTAL & & & & TOTAL \\
\hline
\end{tabular}

Sumber: Hasil analisis, 2016 
ATRIUM, Vol. 3, No. 2, November 2017, 113-134

Tabel 21. Perhitungan radiasi melalui bukaan

\begin{tabular}{|c|c|c|c|c|c|c|c|c|}
\hline \multirow{4}{*}{ No } & \multirow[t]{2}{*}{$(W W R * S C * S F)$} & $\begin{array}{l}\text { Total } \\
\text { Area } \\
\text { Fasad }\end{array}$ & $\begin{array}{c}\text { Total Area } \\
\text { Bukaan }\end{array}$ & \multirow{2}{*}{$\begin{array}{l}\text { Window to } \\
\text { Wall Ratio } \\
\text { (WWR) }\end{array}$} & \multirow[t]{2}{*}{$\begin{array}{c}\text { Solar } \\
\text { Factor (SF) }\end{array}$} & \multirow[t]{2}{*}{$\begin{array}{c}\text { Shading } \\
\text { Coefficient } \\
\text { (SC=SCK*SCeff) }\end{array}$} & \multirow[t]{2}{*}{ OTTV } & (A) $\times$ OTTV \\
\hline & & $\left(m^{2}\right)$ & $\left(\mathbf{m}^{2}\right)$ & & & & & (Watt) \\
\hline & \multirow{2}{*}{ Façade } & (1) & (2) & (3) & (4) & (5) & (6) & (7) \\
\hline & & & & $=(2) /(1)$ & & & $=(3) \times(4) \times(5)$ & $=(1) \times(6)$ \\
\hline S 1 & Single Glass Clear $8 \mathrm{~mm}$ & 152,46 & 17,96 & 0,12 & 97,00 & 0,93 & 10,63 & $1.620,58$ \\
\hline \multirow[t]{3}{*}{ S 2} & Single Glass Clear $8 \mathrm{~mm}$ & 73,06 & 23,26 & 0,32 & 97,00 & 0,93 & 28,73 & $2.098,81$ \\
\hline & & 225,52 & 41,22 & 0,18 & & & & $3.719,39$ \\
\hline & & TOTAL & TOTAL & TOTAL & & & & TOTAL \\
\hline
\end{tabular}

Sumber: Hasil analisis, 2016

\section{Selubung Bangunan/Building Envelope Compliance Form (Orientasi Barat)}

Tabel 22. Identifikasi spesifikasi dinding eksterior

\begin{tabular}{|l|l|l|}
\hline Type & \multicolumn{1}{|c|}{ Konstruksi } & Warna \\
\hline EW 1 & Brick Wall & Coklat tua \\
\hline
\end{tabular}

Sumber: Hasil analisis, 2016

Tabel 23. Identifikasi spesifikasi sistem fenetrasi eksterior

\begin{tabular}{|c|c|c|c|c|c|c|c|}
\hline No & $\begin{array}{c}\text { Kode Tipe } \\
\text { Konstruksi } \\
\text { Sistem } \\
\text { Fenestrasi }\end{array}$ & Nama & SHGC & $\begin{array}{l}\text { U Value } \\
\left(\mathrm{W} / \mathrm{m}^{2} \mathrm{~K}\right)\end{array}$ & $\begin{array}{l}\text { Peneduh } \\
\text { Luar }\end{array}$ & $\begin{array}{c}\text { Kode } \\
\text { Spesifikasi } \\
\text { Peneduh } \\
\text { Luar (lihat } \\
\text { tabel } 3,4,5)\end{array}$ & $\begin{array}{l}\text { SC total } \\
\text { SC } \times \text { Scef }\end{array}$ \\
\hline 1 & F1 & $\begin{array}{l}\text { Single Glass } \\
\text { Clear } 8 \mathrm{~mm}\end{array}$ & 0,8 & 5,8 & yes & SE1 & 0,63 \\
\hline
\end{tabular}

Sumber: Hasil analisis, 2016

Tabel 24. Detail elemen peneduh luar

\begin{tabular}{|c|c|c|c|c|c|c|}
\hline $\mathrm{C}$ & Type : & EGGCRATE & & & & \\
\hline \multirow{2}{*}{ No } & \multirow{2}{*}{$\begin{array}{c}\text { Kode } \\
\text { Peneduh } \\
\text { Luar } \\
\text { Vertikal }\end{array}$} & $\begin{array}{c}\text { panjang } \\
\text { (P1) }\end{array}$ & tinggi $(H)$ & $\begin{array}{c}\text { panjang } \\
(\mathrm{P} 2)\end{array}$ & lebar (W) & kemiringan \\
\hline & & P1 (m) & $H(m)$ & $\mathrm{P} 2(\mathrm{~m})$ & $W(m)$ & [derajat] \\
\hline 1 & SE1 & 1 & 1,95 & 0,3 & 3,15 & 0 \\
\hline
\end{tabular}

Sumber: Hasil analisis, 2016 
Tabel 25. Identifikasi façade

\begin{tabular}{|c|c|c|c|c|c|c|c|c|c|}
\hline \multirow{3}{*}{ No } & \multirow{3}{*}{ FASAD } & \multirow{2}{*}{$\begin{array}{l}\text { Tinggi } \\
\text { (jarak } \\
\text { antar } \\
\text { lantai) }\end{array}$} & \multirow[t]{2}{*}{ Panjang } & $\begin{array}{c}\text { Area } \\
\text { Fasad }\end{array}$ & \multirow{3}{*}{$\begin{array}{c}\text { Tipe } \\
\text { Konstruksi } \\
\text { Dinding }\end{array}$} & \multirow{3}{*}{$\begin{array}{l}\text { Kode Tipe } \\
\text { Konstruksi } \\
\text { Sistem } \\
\text { Fenestrasi }\end{array}$} & $\begin{array}{c}\text { Area } \\
\text { Bukaan }\end{array}$ & $\begin{array}{c}\text { Total } \\
\text { Jumlah } \\
\text { Lantai }\end{array}$ & $\begin{array}{c}\text { Total Area } \\
\text { Fasad }\end{array}$ \\
\hline & & & & [1] & & & [2] & [3] & $=[1] \times[3]$ \\
\hline & & (m) & (m) & $\left(m^{2}\right)$ & & & $\left(m^{2}\right)$ & & $\left(m^{2}\right)$ \\
\hline 1 & $\mathrm{~T} 1$ & 3,96 & 32,25 & 127,71 & EW 1 & $\mathrm{~F} 1$ & 34,62 & 1 & 127,71 \\
\hline 2 & T 2 & 3,96 & 25,75 & 101,97 & EW 1 & F1 & 34,34 & 1 & 101,97 \\
\hline
\end{tabular}

Sumber: Hasil analisis, 2016

Tabel 26. Perhitungan konduksi melalui dinding

\begin{tabular}{|c|c|c|c|c|c|c|c|c|c|c|}
\hline \multirow{4}{*}{ No } & \multirow[t]{2}{*}{ a ((1-WWR)*UW'Tdeq) } & $\begin{array}{c}\text { Total Area } \\
\text { Fasad }\end{array}$ & \multirow{2}{*}{$\begin{array}{c}\text { Heat } \\
\text { Absorbtion } \\
\text { Factor (a) }\end{array}$} & $\begin{array}{c}\text { Total Area } \\
\text { Bukaan }\end{array}$ & \multirow{2}{*}{$\begin{array}{l}\text { Window to Wall } \\
\text { Ratio (WWR) }\end{array}$} & \multirow[t]{2}{*}{ 1-WWR } & \begin{tabular}{|c|}
$\begin{array}{c}\text { U Value (Uv) } \\
\text { wall }\end{array}$ \\
\end{tabular} & \multirow[t]{2}{*}{ TDek } & \multirow[t]{2}{*}{ OTTV } & $\begin{array}{l}\text { (A) } x \\
\text { OTTV }\end{array}$ \\
\hline & & $\left(m^{2}\right)$ & & $\left(m^{2}\right)$ & & & $\left(W / m^{ \pm} k\right)$ & & & (Watt) \\
\hline & \multirow{2}{*}{ Façade } & (1) & (4) & (5) & (6) & (7) & (8) & (9) & (10) & (11) \\
\hline & & & & & $=(5) /(1)$ & $=1-(6)$ & & & $=(4) \times(7) \times(8) \times(9)$ & $=(1) \times(10)$ \\
\hline T1 & Brick Wall & 127,71 & 0,88 & 34,62 & 0,27 & 0,73 & 2,80 & 10,00 & 17,94 & $2.291,69$ \\
\hline \multirow[t]{3}{*}{$\mathrm{T} 2$} & Brick Wall & 101,97 & 0,88 & 34,34 & 0,34 & 0,66 & 2,80 & 10,00 & 16,33 & $1.664,92$ \\
\hline & & 229,68 & & 68,96 & 0,30 & & & & & $3.956,61$ \\
\hline & & TOTAL & & TOTAL & TOTAL & & & & & TOTAL \\
\hline
\end{tabular}

Sumber: Hasil analisis, 2016

Tabel 27. Perhitungan konduksi melalui bukaan

\begin{tabular}{|c|c|c|c|c|c|c|c|c|}
\hline \multirow{4}{*}{ No } & \multirow[t]{2}{*}{$(W W R * U f * \Delta T)$} & $\begin{array}{c}\text { Total Area } \\
\text { Fasad }\end{array}$ & $\begin{array}{l}\text { Total Area } \\
\text { Bukaan }\end{array}$ & \multirow{2}{*}{$\begin{array}{l}\text { Window to } \\
\text { Wall Ratio } \\
\text { (WWR) }\end{array}$} & $\begin{array}{l}\text { U Value } \\
\text { Bukaan }\end{array}$ & \multirow[t]{2}{*}{$\Delta \mathrm{T}$} & \multirow[t]{2}{*}{ OTTV } & (A) $x$ OTTV \\
\hline & & $\left(m^{2}\right)$ & $\left(m^{2}\right)$ & & $\left(W / m^{2} K\right)$ & & & (Watt) \\
\hline & \multirow{2}{*}{ Façade } & (1) & (2) & (3) & (4) & $(5)$ & (6) & (7) \\
\hline & & & & $=(2) /(1)$ & & & $=(3) \times(4) \times(5)$ & $=(1) \times(6)$ \\
\hline T 1 & $\begin{array}{l}\text { Single Glass Clear } \\
8 \mathrm{~mm}\end{array}$ & 127,71 & 34,62 & 0,27 & 5,80 & 5,00 & 7,86 & $1.003,98$ \\
\hline \multirow[t]{3}{*}{ T 2} & $\begin{array}{l}\text { Single Glass Clear } \\
8 \mathrm{~mm}\end{array}$ & 101,97 & 34,34 & 0,34 & 5,80 & 5,00 & 9,77 & 995,86 \\
\hline & & 229,68 & 68,96 & 0,30 & & & & $1.999,84$ \\
\hline & & TOTAL & TOTAL & TOTAL & & & & TOTAL \\
\hline
\end{tabular}

Sumber: Hasil analisis, 2016

Tabel 28. Perhitungan radiasi melalui bukaan

\begin{tabular}{|c|c|c|c|c|c|c|c|c|}
\hline \multirow[t]{3}{*}{ No } & (WWR*SC*SF) & $\begin{array}{c}\begin{array}{c}\text { Total } \\
\text { Area } \\
\text { Fasad }\end{array} \\
\left(\mathrm{m}^{2}\right)\end{array}$ & $\begin{array}{c}\text { Total Area } \\
\text { Bukaan } \\
\left(\mathrm{m}^{2}\right)\end{array}$ & $\begin{array}{l}\text { Window to } \\
\text { Wall Ratio } \\
\text { (WWR) }\end{array}$ & $\begin{array}{c}\text { Solar } \\
\text { Factor (SF) }\end{array}$ & $\begin{array}{c}\text { Shading } \\
\text { Coefficient } \\
\text { (SC=SCK*SCeff) }\end{array}$ & OTTV & $\begin{array}{c}\text { (A) } \times \text { OTTV } \\
\text { (Watt) }\end{array}$ \\
\hline & \multirow{2}{*}{ Façade } & (1) & (2) & (3) & (4) & (5) & (6) & (7) \\
\hline & & & & $=(2) /(1)$ & & & $=(3) \times(4) \times(5)$ & $=(1) \times(6)$ \\
\hline B 1 & Single Glass Clear $8 \mathrm{~mm}$ & 127,71 & 34,62 & 0,27 & 243,00 & 0,63 & 41,47 & $5.296,45$ \\
\hline \multirow[t]{3}{*}{ B 2} & Single Glass Clear $8 \mathrm{~mm}$ & 101,97 & 34,34 & 0,34 & 243,00 & 0,63 & 51,52 & $5.253,62$ \\
\hline & & 229,68 & 68,96 & 0,30 & & & & $10.550,07$ \\
\hline & & TOTAL & TOTAL & TOTAL & & & & TOTAL \\
\hline
\end{tabular}

Sumber: Hasil analisis, 2016 
Pada tabel analisis diatas, identifikasi material dinding menggunakan pasangan bata, sedangkan material bukaan menggunakan kaca bening $8 \mathrm{~mm}$. Hasil Perhitungan OTTV setiap sisi fasad (lantai 1 dan lantai 2) bangunan ini untuk sisi Utara mempunyai nilai OTTV 44,18 Watt $/ \mathrm{m}^{2}$, sisi Timur mempunyai nilai OTTV $47,10 \mathrm{Watt} / \mathrm{m}^{2}$, sisi Selatan mempunyai nilai OTTV 41,91 Watt $/ \mathrm{m}^{2}$, dan sisi Barat mempunyai nilai OTTV 71,87
Watt $/ \mathrm{m}^{2}$. Kemudian nilai rata-rata OTTV keseluruhan bangunan adalah $\quad 51,34 \quad \mathrm{Watt} / \mathrm{m}^{2}$. Berdasarkan hasil analisa tersebut, nilai OTTV semua sisi bangunan belum memenuhi standart nilai yang ditetapkan oleh pemerintah $\left(<35 \mathrm{Watt} / \mathrm{m}^{2}\right)$, maka diperlukan elemen fasad seperti sun shading dengan material yang dapat mereduksi panas untuk pelindung efek radiasi sinar matahari yang masuk ke ruangan.

Tabel 29. Nilai OTTV keseluruhan façade bangunan

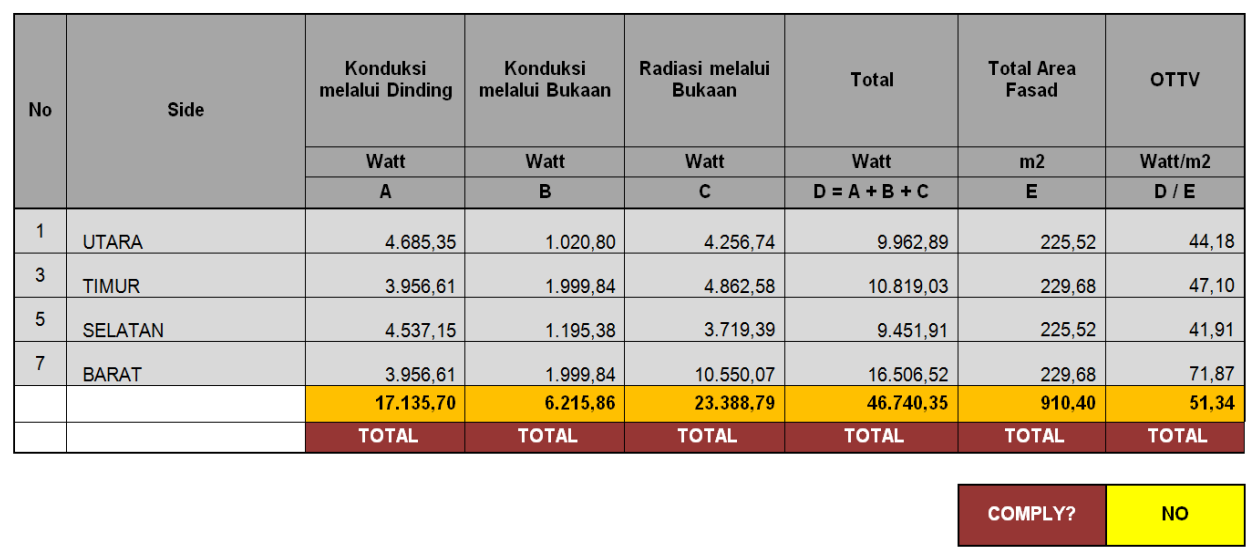

Sumber: Hasil analisis, 2016

Nilai perbandingan selubung bangunan transparan dengan selubung bangunan masif (Window to Wall Ratio / WWR) pada bangunan ini adalah $23,54 \%$ dengan luas area bukaan 214,34 $\mathrm{m}^{2}$ sudah memenuhi standar nilai yang ditetapkan oleh pemerintah $(<30 \%)$

Tabel 30. Nilai WWR keseluruhan façade bangunan

\begin{tabular}{|c|l|c|c|}
\hline \multirow{2}{*}{ No } & \multirow{2}{*}{ Side } & $\begin{array}{c}\text { Total Area } \\
\text { Bukaan }\end{array}$ & WWR \\
\cline { 3 - 4 } & & $\mathbf{m} 2$ & $(\%)$ \\
\cline { 3 - 4 } & & $\mathbf{F}$ & $\mathbf{F} / \mathbf{E}$ \\
\hline 1 & UTARA & 35,20 & 15,61 \\
\hline 2 & TIMUR & 68,96 & 30,02 \\
\hline 3 & SELATAN & 41,22 & 18,28 \\
\hline 4 & BARAT & 68,96 & 30,02 \\
\hline & & 214,34 & 23,54 \\
\hline & & TOTAL & TOTAL \\
\hline
\end{tabular}

Sumber: Hasil analisis, 2016 
b. Sistem Ventilasi/Pengkondisian Udara

Sistem ventilasi/penghawaan pada gedung PIP2B untuk lantai 1 menggunakan penghawaan alami dengan konsep cross ventilation, namun bukaan bovenlicht di atas jendela tertutup dengan kaca mati. Untuk lantai 2 masih menggunakan Air Conditioning (AC). Jika ruangan diharuskan menggunakan AC karena faktor adanya barang-barang perkantoran yang tidak boleh terkena udara luar, maka persyaratan AC yang digunakan adalah:

- AC tipe inverter R410/R32. AC ini dapat menyesuaikan suhu minimal $25^{\circ} \mathrm{C} \pm 1{ }^{\circ} \mathrm{C}$, konsumsi daya listrik lebih rendah, dan Freon AC non-CFC/nonHCFC.

- AC tipe Variable Refrigerant Volume (VRV), jenis AC di mana 1 (satu) unit outdoor dapat mendukung beberapa unit indoor.

\section{c. Sistem Pencahayaan}

Untuk pencahayaan alami, kekuatan cahaya di dalam ruang diukur menggunakan luxmeter dengan standar maksimal kekuatan cahaya 300 lux. Pengukuran dapat dilakukan jika kekuatan cahaya di luar bangunan sudah mencapai 10.000 lux saat siang hari dan cuaca cerah.

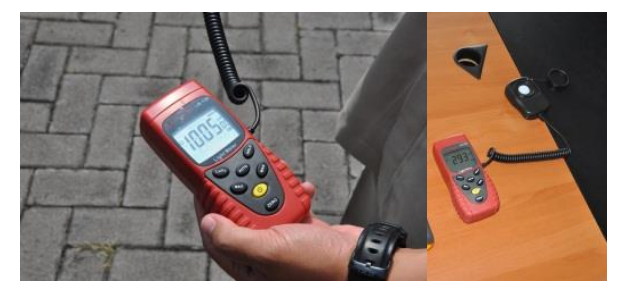

Gambar 3. Pengukuran kekuatan cahaya di luar dan dalam bangunan Sumber: Hasil survei, 2016
Hasil pengukuran kekuatan cahaya di bangunan PIP2B menunjukan angka 293 lux, sehingga sudah sesuai standar tingkat pencahayaan alami.

Untuk Pencahayaan buatan pada bangunan PIP2B perlu diterapkan daerah yang mendapatkan cahaya alami memiliki pengelompokan lampu terpisah dengan daerah yang tidak mendapatkan cahaya alami, lampu yang digunakan sebaiknya lampu LED dan dilengkapi dengan sensor photoelectric.

d. Sistem Kelistrikan

Perencanaan sistem kelistrikan pada konsep Bangunan Gedung Hijau dimaksudkan untuk menghindari potensi pemborosan energi. Gedung PIP2B dengan daya listrik 33000 VA dan luas bangunan $1882 \mathrm{~m}^{2}$, tercatat penggunaan listrik rata-rata adalah 282916 watt atau 150,32 watt/luas. Penggunaan listrik dapat dipantau dengan pemasangan sub meter pada panel listrik yang berfungsi untuk memantau beban listrik keseluruhan, beban listrik lampu, beban listrik stop kontak, dan beban listrik AC.

Dalam memanfaatkan efisiensi sumber terbarukan, penggunaan solar panel dan solar water heater yang mengubah energi cahaya matahari menjadi energi listrik dapat menghemat penggunaan beban listrik, menurunan emisi karbon dioksida, dan perawatan relatif mudah. 


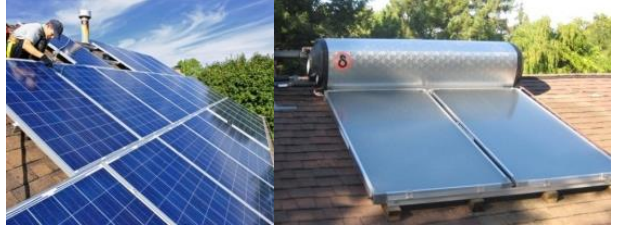

Gambar 4. Pemasangan solar panel dan solar water heater

Sumber: Hasil survei, 2016

3. Efisiensi Penggunaan Air

a. Sumber Air

Sumber air gedung PIP2B menggunakan air tanah (sumur air bersih) tanpa ada pengolahan daur ulang. Seharusnya penggunaan air tanah menerapkan sistem daur ulang dan memasang meteran air untuk memantau konsumsi air. Hasil perhitungan penggunaan air per bulan pada gedung PIP2B ratarata: $59,15 \mathrm{~m}^{3}$ atau $0,031 \mathrm{~m}^{3} /$ luas.

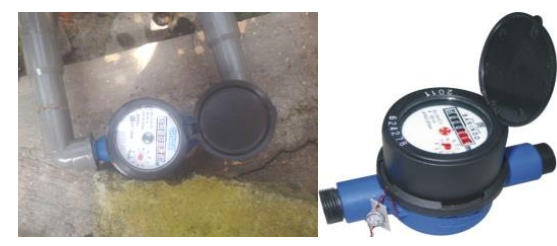

Gambar 5. Pemasangan meteran air Sumber: Hasil survei, 2016

b. Penggunaan Peralatan Saniter Hemat Air (Water Fixture)

Penggunaan peralatan saniter hemat air pada ruang lavatory gedung PIP2B yaitu: jet shower pada closet dan urinoir. Penggunan kran dan ember masih ada di setiap toilet, sehingga konsumsi air lebih banyak. Kran wastafel juga masih menggunakan tipe konvensional. Hasil pengamatan di gedung PIP2B hanya menggunakan $25 \%$ produk saniter hemat energi. Seharusnya perlu diterapkan produk kran otomatis yang dilengkapi dengan sensor/auto stop. Standar Water Fixture diuji dalam tekanan 0,7 bar menghasilkan closet flush tank 6 liter/flush, urinal flush 4 liter/flush, shower 9 liter/menit, kran wastafel 8 liter/menit.

4. Kualitas Udara dalam Ruang Sekitar $80 \%$ waktu kita dihabiskan untuk beraktivitas di dalam ruangan. Tentunya kualitas udara yang buruk akan berpengaruh terhadap kesehatan kita. Sumber pencemaran udara di dalam ruangan antara lain berasal dari emisi dan bising dari lalu lintas kendaraan di luar gedung, kinerja alatalat di dalam gedung, emisi perabot, material bangunan, dan gangguan sistem ventilasi udara. Pengendalian kualitas udara dalam ruangan memerlukan strategi yang tepat sehingga produktivitas kerja serta tingkat okupansi gedung dapat berlangsung secara optimal. Hasil pengamatan di lapangan adalah:

a. Gedung PIP2B tidak ada peletakan penanda (signage) pelarangan merokok, seharusnya dipasang signage pelarangan merokok pada setiap dinding ruangan.

b. Gedung PIP2B juga tidak ada alat pemantauan kadar CO2/karbon dioksida yang dipasang. Hasil Pengukuran kadar $\mathrm{CO} 2$ dengan alat $\mathrm{CO} 2$ meter menunjukan angka 0.00 - 0.07, hal ini menunjukan bahwa kualitas udara ruangan relatif bersih. Seharusnya ruangan memiliki alat monitor $\mathrm{CO} 2$ dan alarm jika kadar $\mathrm{CO} 2$ ruangan melewati ambang batas.

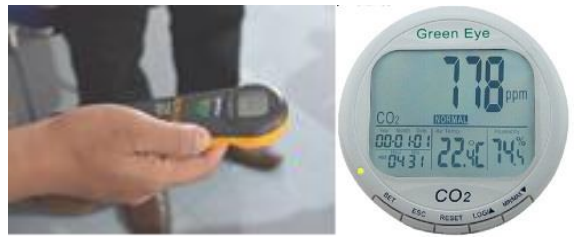

Gambar 6. Pengukuran kadar $\mathrm{CO} 2$ dan contoh alat sensor $\mathrm{CO} 2$ Sumber: Hasil survei, 2016 
5. Material Ramah Lingkungan

Material ramah lingkungan merupakan elemen dari desain pasif. Sebagai elemen dari desain pasif, material dikaitkan dengan kemampuannya dalam mendukung kinerja gedung secara efisien dan efektif untuk memenuhi kebutuhan penggunannya. Hal ini secara langsung berhubungan dengan karakteristik yang dimiliki material tersebut dalam merespon isu ramah lingkungan dalam bangunan gedung.

Material yang ramah lingkungan seharusnya memiliki konsep desain ekologi pada rangkaian proses pembuatan, pengangkutan dan pemasangan. Sedangkan dari aspek ekonomi, material ramah lingkungan dilihat dari aspek asal bahan baku dan tempat produksinya.

Kriteria material yang ramah lingkungan bisa dengan penggunaan material lokal, menggunakan material bekas, daur ulang, prefabrikasi, atau material yang memiliki fitur ramah lingkungan (seperti hemat air, hemat energi, mudah pemeliharaan). Bisa juga memilih material yang industrinya telah menerapkan ramah lingkungan pada proses produksinya. Hasil pengamatan di lapangan:

- Material penutup atap dominan di gedung PIP2B adalah genteng dan sebagian dak beton, sehingga tidak direncanakan menggunakan asbestos.

- Material cat yang ada sesuai ketentuan tidak mengandung zat pencemar berbahaya, sesuai dengan anti bakteria dan mudah dibersihkan. Bahan dasar pengencer cat menggunakan air (water base).

- Material kayu, bambu, dan material terbarukan tidak terdapat perekat atau pelapis dengan zat pencemar berbahaya.

- Material logam menggunakan pelapis cat tahan karat yang tidak mengandung zat pencemar berbahaya.

- Material beton menggunakan pasir dan kerikil berasal dari sumber lokal, maksimum $1000 \mathrm{~km}$ dari lokasi proyek.

\section{Pengelolaan Sampah}

Sistem pengelolaan sampah harus menerapkan Prinsip 3 R (Reduce, Reuse, Recycle). Pengaturan pengelolaan di Gedung PIP2B belum menerapkan prinsip tersebut. Kriteria yang harus diterapkan dalam pengelolaan sampah adalah:

- Melaksanakan pembukuan retribusi sampah perbulan dan pencatatan berat/volume timbulan sampah.

- Melaksanakan usaha pengurangan dan penggunaan kembali kantong plastik dan kertas.

- Membangun tempat pembuangan sampah sementara (TPS) dalam tapak dan menempatan fasilitas tempat sampah

- Memisahan sampah organik dan sampah anorganik.

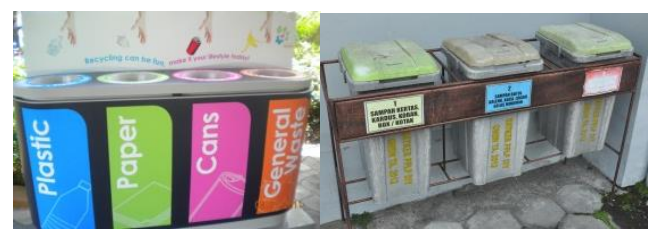

Gambar 7. Pemisahan sampah organik dan sampah anorganik

Sumber: Hasil survei, 2016

\section{Pengelolaan Air Limbah}

Pengelolaan air limbah di gedung PIP2B hanya ditampung di septictank, kemudian langsung diresapkan ke sumur peresapan, tanpa ada proses pengolahan. 
Penyediaan fasilitas pengolahan limbah sebelum dibuang ke saluran pembuangan kota sangat penting untuk menjaga kelestarian lingkungan. Hasil daur ulang air yang berasal dari limbah cair dengan water treatment plan dapat disaring kembali sehingga menjadi air bersih kualitas 2 yang dapat dimanfaatkan untuk flushing toilet dan siram tanaman. Air ini harus memenuhi standar kualitas air yang boleh diresapkan ke dalam tanah.

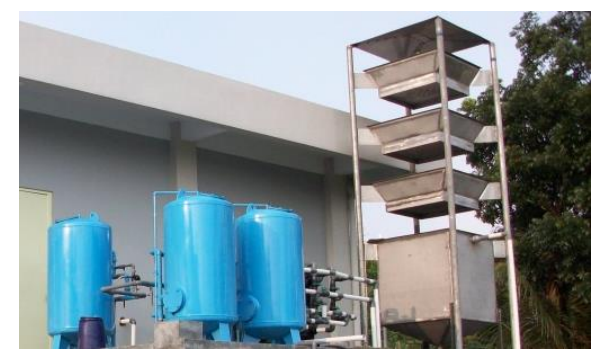

Gambar 8. Water treatment plan Sumber: Hasil survei, 2016

\section{Persebaran Vegetasi}

Elemen vegetasi sebagai pendukung konsep arsitektur hijau bertujuan untuk mewujudkan desain ekologis pada bangunan. Berdasarkan fungsinya, vegetasi diklasifikasikan sebagai peneduh, pengarah, pembatas, penghalang dan ground cover.

Hasil pengamatan dilapangan, vegetasi peneduh pada tapak gedung PIP2B hanya satu jenis, yaitu pohon Ketapang yang terletak di halaman parkir mobil sisi Utara gedung dengan jumlah 25 pohon. Untuk satu pohon ketapang rata-rata dengan tajuk diameter $8 \mathrm{~m}$ memiliki area perindang $50,24 \mathrm{~m}^{2}$, sehingga nilai jumlah tajuk vegetasi dibanding area tapak sudah memenuhi standar minimal 20\%. Vegetasi lain yang ada di tapak hanya berupa tanaman hias yang hanya berfungsi sebagai estetika.

\section{Kesimpulan}

Arsitektur hijau dapat diterapkan dari tahap perencanaan, tahap konstruksi, tahap pemanfaatan sampai dengan tahap renovasi pada pengembangan desain gedung pemerintahan untuk mewujudkan bangunan gedung hijau dengan memperhatikan faktor-faktor yang mempengaruhinya, antara lain:

1. Pengelolaan tapak dan bangunan, dengan orientasi bukaan bangunan menghadap sisi Utara atau Selatan untuk meminimalkan efek radiasi sinar matahari secara langsung, penyediaan jalur sirkulasi sepeda dan parkir sepeda, penyediaan jalur sirkulasi pedestrian terlindung dari panas sinar matahari dilengkapi ramp (sudut kemiringan $7^{0}$ ) bagi aksesibilitas difabel, penyediaan jalur sirkulasi kendaraan dan parkir kendaraan dilengkapi rambu-rambu (signage), serta menambah persentase luasan ruang terbuka hijau dengan ground cover rumput dan vegetasi sebesar 50\% dari luasan tapak sebagai daerah tangkapan air hujan atau resapan air.

2. Penempatan persebaran vegetasi, dengan pemilihan jenis tanaman yang berfungsi sebagai penghalang radiasi sinar matahari, pengarah, peneduh, peredam suara, penyaring debu dan bau, serta mudah perawatannya. Penempatan vegetasi pada façade bangunan menggunakan tanaman merambat seperti lee kwan yu atau sirih Belanda. Penempatan vegetasi pada ruang terbuka hijau dan area parkir kendaraan menggunakan pohon ketapang atau biola cantik dengan ketentuan 
nilai jumlah tajuk vegetasi dibanding area tapak minimal $20 \%$ dan tanaman merupakan budidaya lokal minimal $60 \%$.

3. Efisiensi penggunaan energi, dengan sistem selubung bangunan memiliki nilai OTTV kurang dari $35 \mathrm{watt} / \mathrm{m}^{2}$ dan nilai perbandingan selubung bangunan transparan dengan selubung bangunan masif $(W W R)$ kurang dari 30\%, sistem ventilasi dalam ruang dengan penghawaan alami (cross ventilation) dan penghawaan buatan menggunakan $A C$ tipe inverter $/ V R V$, sistem pencahayaan alami dalam ruang dengan kekuatan cahaya maksimal 300 lux dan pencahayaan buatan menggunakan lampu LED dilengkapi dengan sensor, serta sistem kelistrikan dengan pemasangan sub meter dan penggunaan solar panel memanfaatkan energi panas matahari.

4. Efisiensi penggunaan air, dengan pemanfaatan PDAM, penggunaan air tanah dilengkapi meteran air, dan penggunaan peralatan saniter hemat air (shower, closet, urinoir, kran otomatis).

5. Kualitas udara dalam ruang, dengan pemasangan penanda (signage) pelarangan merokok dan pemasangan alat pemantau kadar $\mathrm{CO} 2$ di dalam ruangan.

6. Penggunaan material ramah
lingkungan, menggunakan material lokal yang mudah mendapatkannya, tidak mengandung zat pencemar berbahaya bagi kesehatan penghuni, material terbarukan atau dapat didaur ulang dan bersertifikat ramah lingkungan (eco labelling).

7. Pengelolaan pesampahan, dengan penyediaan fasilitas tempat sampah yang dipisah antara sampah organik dan sampah anorganik supaya mudah untuk diproses daur ulang, penyediaan tempat pembuangan sampah sementara (TPS) di area tapak, dan melakukan pencatatan volume sampah secara periodik.

8. Pengelolaan air limbah, dengan sistem water treatment plan hasil daur ulang air yang berasal dari limbah cair dapat disaring kembali sehingga menjadi air bersih kualitas 2 yang dapat dimanfaatkan untuk flushing toilet dan siram tanaman, sehingga memenuhi standar kualitas air yang boleh diresapkan ke dalam tanah.

\section{Daftar Pustaka}

ERG. (1994). Bioclimatic architecture brocure. Dublin: University College Dublin.

Frick, H. dan F.X. Bambang Suskiyatno. (1998). Dasardasar eko-arsitektur. Yogyakarta: Kanisius.

Hamzah, T.R. dan Yeang. (2001). Ecology of the sky. Victoria: Images Publishing Group Pty. Ltd.

IPCC. (2007). Fourth assesment report on climate change.

Karyono, T. H. (2010). Green architecture: pengantar pemahaman arsitektur hijau di Indonesia. Jakarta: PT. Raja Grafindo Persada.

Murcheff, F. D. (1996). Principles of sustainable development. 
Wellington: Butterworth Architecture.

Peraturan Menteri Pekerjaan Umum dan Perumahan Rakyat. No.2. (2015). Bangunan gedung hijau.

Peraturan Presiden RAN-GRK. (2011). Rencana aksi nasional penurunan emisi gas rumah kaca.

Vale, R. dan Brenda. (1991). Green architecture design for sustainable future. London: Thames and Hudson.

Yeang, K. (1996). The skyscraper, bioclimatically considered. London: Academy. 